\title{
ANALISIS NILAI MORAL BAHASA GAUL (ALAY) TERHADAP PENDIDIKAN REMAJA PADA MEDIA SOSIAL
}

\author{
Hanana Muliana ${ }^{1}$ Sumarni $^{2}$
}

\author{
Fakultas Keguruan dan Ilmu Pendidikan, Universitas Muhammadiyah Makassar \\ syamsul.alam@gmail.com \\ Fakultas Keguruan dan Ilmu Pendidikan, Universitas Muhammadiyah Makassar \\ sumarni@gmail.com
}

\begin{abstract}
The problems of study related to moral values in Alay language. The problem seen through the formulation of the problem, namely the moral values of what are contained in slang (Alay) on social media against youth education? The purpose of this study was to describe about moral values slang (Alay) on social media on youth education. In order to contribute to the community that over the times, good language and appropriate arrangements to speak not as a language Alay rampant in social networks. This research was a study that contains some excerpts or statements contained in Alay language socially mediated. As for this research technique used in this study is documentation technique to collect the articles and surveys of the print media. The results showed that the value penddikan contained in bahsa Alay are: (1) the value of religious education include: ethics speak, the ethical use of the time (2) the value of cultural education includes: the value of Indonesian, the value of the mother tongue, language scores Alay and value slang (3) the value of psychological education include: lifestyle and mindset
\end{abstract}

Keywords: moral values, language Alay, social media

\begin{abstract}
Abstrak
Masalah dalam penelitian ini berkaitan dengan nilai-nilai moral dalam bahasa Alay. Masalah tersebut dilihat melalui rumusan masalah, yaitu Nilai-nilai moral apa sajakah yang terdapat dalam bahasa gaul (Alay) pada media sosial terhadap pendidikan remaja? Tujuan penelitian ini adalah mendeskripsikan tentang nilai-nilai moral bahasa gaul (Alay) pada media sosial terhadap pendidikan remaja. Guna memberikan sumbangsih kepada masyarakat bahwa seiring perkembangan zaman, bahasa yang baik dan sesuai tatanan berbahasa bukan seperti bahasa Alay yang marak dalam jejaring sosial . Jenis penelitian ini adalah penelitian yang berisi kutipan beberapa atau pernyataan yang terdapat dalam bahasa Alay dimedia sosial. Adapun teknik penelitian ini yang digunakan dalam penelitian ini adalah teknik dokumentasi dengan jalan mengumpulkan artikel-artikel dan hasil survei dari media cetak. Hasil penelitian menunjukkan bahwa nilai penddikan yang terdapat dalam bahsa Alay adalah: (1) nilai pendidikan agama meliputi: etika berbicara, etika menggunakan waktu (2) nilai pendidikan budaya meliputi: nilai bahasa Indonesia, nilai bahasa ibu, nilai bahasa Alay dan nilai bahasa prokem (3) nilai pendidikan psikologis meliputi: gaya hidup dan pola pikir
\end{abstract}

Kata Kunci: nilai moral, bahasa Alay, media sosial

\section{PENDAHULUAN}

Menjamurnya internet dan situs-situs jejaring sosial juga berdampak signifikan terhadap perkembangan bahasa gaul. Penikmat situs-situs jejaring sosial yang kebanyakan adalah remaja, menjadi agen dalam menyebarkan pertukaran bahasa gaul.
Tulisan seorang remaja di situs jejaring sosial yang menggunakan bahasa ini, akan dilihat dan bisa jadi ditiru oleh ribuan remaja lain. Bila ditelusuri, bahasa gaul juga muncul di kalangan anak sekolah dasar karena pengaruh lingkungan. Umumnya mereka menyerap dari percakapan orang-orang dewasa di sekitarnya. Atau meniru dari media massa, 
semisal dari adegan percakapan di televisi maupun mengikuti tren bahasa gaul di media cetak. Yang pasti, bahasa gaul akan selalu muncul dan berkembang sesuai zaman masing-masing. Beberapa tahun lalu, istilah "memble aje" atau "Biarin, yang penting kece" sempat ngetren. Istilah-istilah tersebut lantas tenggelam dengan sendirinya, tergantikan oleh istilah lain. Di antaranya, "so what gitu loh", “jayus”

Mengapa anak usia SD? Tak lain karena dorongan untuk meniru lingkungan amat kuat dalam diri anak usia sekolah dasar. Ini merupakan tanda bahwa mereka tengah berusaha untuk beradaptasi dan bersosialisasi dengan lingkungannya. Tak heran kalau ada temannya yang menggunakan bahasa gaul sebagai bahasa sehari-hari biasanya ia juga akan menggunakan bahasa yang sama saat berkomunikasi dengan teman-temannya.

Allah subhanahu wata'ala berfirman yang artinya:

"Hai orang-orang yang beriman, bertakwalah kamu sekalian kepada Allah dan katakanlah perkataan yang benar, niscaya Allah memperbaiki amalan-amalanmu dan mengampuni dosa-dosamu. Barangsiapa mentaati Allah dan Rasul-Nya, maka sesungguhnya ia telah mendapat kemenengan yang besar" [Al-Ahzab : 70-71]

Dari terjemahan ayat diatas terlihat jelas bahwa Allah memerintahkan kita untuk berkata (berbahasa) dengan benar, sehingga dapat disimpulkan bahwa bahasa Alay merupakan bahasa yang tidak baik dan kurang benar karena secara tidak sadar bahasa Alay dalam dunia maya (media sosial) akan dapat mempengaruhi terhadap dunia nyata terutama pada perkembangan bahasa Indonesia yang baik dan benar dikalangan remaja.

Menurut pakar komunikasi 70\% dalam 24 jam, waktu manusia diisi dengan komunikasi. Begitu banyaknya waktu yang kita habiskan dalam komunikasi. Salah komunikasi atau misscommunication akan mengakibatkan salah presepsi. Rasulullah Shallalahu 'alaihi wasallam adalah komunikator yang hebat, setiap pesan yang beliau sampaikan pasti berkesan dihati para sahabat, bahkan dihati kaum kafir yang memusuhinya.

Didalam keseharian kita, ada beberapa hal-hal yang harus diperhatikan yaitu:

- Bagaimana saya harus berbicara?

- Bagaimana memilih kata-kata yang tepat dalam berbicara?

- Bagimana menguasai materi agar pembicaraan tidak ditertawakan orang?

- Kenapa setiap ide yang saya coba utarakan ternyata hilang?

- Bagimana memulai pembicaraan?

Sederetan pertanyaan itulah yang kerap kali kita jumpai, mungkin juga pernah atau bahkan sedang mengalami hal seperti itu. Pertanyaan-pertanyaan itu tentu tidak salah untuk diutarakan, dan pertanyaan tersebut perlu dicari solusinya. Dengan berbagai langkah, tentu kita harus dapat berbicara dengan fasih dan lancar sebagaimanan kedua orang tua kita mengajari kita supaya bisa berbahasa dengan benar, fasih jelas, dan dapat dipahami.

Alay adalah singkatan dari Anak layangan, Alah lebay, Anak layu atau Anak kelayapan yang menghubungkannya dengan anak jarpul (Jarang Pulang). Tapi yang paling terkenal adalah Anak layangan. Dominannya, istilah ini menggambarkan anak yang menganggap dirinya keren secara gaya busananya.

Pesatnya perkembangan teknologi dizaman modern ini, penggunaan media sosial lewat internet ini banyak diminati kalangan remaja. Jumlah pengguna bahasa Alay menunjukkan semakin akrabnya genersai muda Indonesia dengan dunia maya tersebut. 
Munculnya bahasa Alay juga menunjukkan adanya perkembangan zaman yang dinamis, karena suatu bahasa harus menyesuaikan dengan masyarakat penggunanya agar tetap eksis. Akan tetapi, munculnya bahasa Alay juga merupakan sinyal ancaman yang sangat serius terhadap bahasa Indonesia dan pertanda semakin buruknya kemampuan berbahasa generasi muda zaman sekarang. Dalam ilmu linguistik memang dikenal adanya beragam-ragam bahasa baku dan tidak baku. Bahasa baku biasanya digunakan dalam acara-acara yang kurang formal. Akan tetapi, bahasa Alay merupakan bahasa gaul yang tidak mengindah. Dapat disimpulkan bahwa penggunaan bahasa Alay untuk generasi muda saat ini sudah sangat tidak mnegindahkan efesiensi, melainkan hanya sekedar trend belaka (Misbakhul Munir, Guru SD Al-Azhar Syifa Budi, Solo) Secara garis besar, mungkin karena salah pergaulan, maka yang merupakan ciri-ciri Alay adalah sebagai berikut.

1. Pada account facebook atau friendster, bagi yang cewek di album fotonya memajang cowok-cowok ganteng meskipun tidak kenal supaya dianggap cantik dan gaul. Untuk yang cowok, majang foto cewek semua walau tidak kenal agar disangka cowok ganteng. Banyak yang tidak menyadari bahwa internet juga menjadi ranah kejahatan terhadap perempuan. "Tidak ada yang menjaga hak-hak perempuan di internet" Ungkap Nani Buntarin, aktivis perempuan yang sejak tahun 1998 menginisiasi pengguna mailing list untuk gerakan perempuan. Hali ini terungkap dalam diskusi Perempuan di Kedai Tjikini, Rabu, 24/10/2012 lalu. Dalam acara yang diselenggarakan oleh Komnas Perempuan bekerjasama dengan Jaringan Perempuan Eksplorasi Hak Internet dan
Seksualitas tersebut, terungkap berbagai pengalaman kekerasan terhadap perempuan di internet.

Sebuah media memberitakan belum lama ini pihak kepolisian berhasil mengungkap kejahatan yang menawarkan peempuan secara online. Sangat memprihatinkan karena kejahatan tersebut baru terungkap setelah dua tahun beroperasi.

2. Suka ngirim 'status' tidak jelas misalnya "ngantuk tidur yuk" Kalimat tersebut memang sepele. Namun, bagi mereka yang belum tahu adab-adab berbicara dengan lawan jenis maka akan berbeda hasilnya. Benar saja, berbagai komentar segera muncul menanggapi status tersebut. Ada yang menanggapi serius tetapi kebanyakan hanya menggoda bahkan beberapa menggoda lebih jauh lagi, menjurus kehubungan pasutri.

3. Menganggap dirinya eksis di Friendster atau Facebook atau Multiply (kalau

comments banyak berarti anak gaul, menjadi lomba banyak comment)

Curhat (curahan hati) memang menyenangkan. Namun, sebaiknya lihatlah tempat jika ingin curhat dan gunakan cara yang konvensional dibanding melakukannya di media pertemanan tersebut. Jika semua permasalahan yang Anda ditampilkan maka Anda bisa dianggap tidak profesional. Sebaiknya tuliskan hal-hal yang lebih positif yang membuat orang lain bersemangat.

4. Kalau ada orang yang hanya melihat profil user di media sosial, lalu mengirim testimonial: "hey cuman view nih?" atau "heey jgn cuman view doang, add dong! Jawablah pesan dari teman Anda jika mereka menanyakan sesuatu. Namun, abaikan saja jika ada yang mengirimkan pesan negatif. Link aktif atau tautan yang tersebar diberbagai situs, grup atau 
komentar semakin banyak. Namun, sebaiknya Anda jangan sembarang mengikutinya karena sebagian link biasanya hanya jebakan.

5. Nama profil media sosial mengagungagungkan diri sendiri, seperti: Bocah

nakal, gadis liar dan lain-lain. Padahal sudah dikabarkan dalam sebuah ayat bahwa janganlah saling memanggil dengan gelar-gelar yang buruk. Seburuk-buruk panggilan adalah adalah panggilan yang (fasik) setelah beriman.

Dari ciri-ciri diatas, dapat diketahui bahwa bahasa Alay sudah berkembang pesat dimedia sosial terutama facebook dan twitter.

Bahasa gaul adalah dialek bahasa Indonesia nonformal yang digunakan oleh komunitas tertentu atau di daerah tertentu untuk pergaulan (KBBI, 2008: 116). Bahasa gaul identik dengan bahasa percakapan (lisan). Bahasa gaul muncul dan berkembang seiring dengan pesatnya penggunaan teknologi komunikasi dan situs-situs media sosial. Bahasa gaul pada umumnya digunakan sebagai sarana komunikasi di antara remaja sekelompoknya selama kurun tertentu.

Hal ini dikarenakan, remaja memiliki bahasa tersendiri dalam mengungkapkan ekspresi diri. Sarana komunikasi diperlukan oleh kalangan remaja untuk menyampaikan hal-hal yang dianggap tertutup bagi kelompok usia lain atau agar pihak lain tidak dapat mengetahui apa yang sedang dibicarakannya. Masa remaja memiliki karakteristik antara lain petualangan, pengelompokan, dan kenakalan. Ciri ini tercermin juga dalam bahasa mereka. Keinginan untuk membuat kelompok eksklusif menyebabkan mereka menciptakan bahasa rahasia (Sumarsana dan Partana, 2002:150).
Menurut Owen (dalam Papalia: 2004) remaja mulai peka dengan kata-kata yang memiliki makna ganda. Mereka menyukai penggunaan metafora, ironi, dan bermain dengan katakata untuk mengekspresikan pendapat mereka. Terkadang mereka menciptakan ungkapan-ungkapan baru yang sifatnya tidak baku. Bahasa seperti inilah yang kemudian banyak dikenal dengan istilah bahasa gaul. Di samping merupakan bagian dari proses perkembangan kognitif, munculnya penggunaan bahasa gaul juga merupakan ciri dari perkembangan psikososial remaja.

Menurut Erikson (1968), remaja memasuki tahapan psikososial yang disebut sebagai identity versus role confusion. Hal yang dominan terjadi pada tahapan ini adalah pencarian dan pembentukan identitas. Remaja ingin diakui sebagai individu unik yang memiliki identitas sendiri yang terlepas dari dunia anak-anak maupun dewasa.

\section{METODE PENELITIAN}

\section{a. Desain Penelitian}

Desain penelitian pada hakikatnya merupakan strategi yang mengatur ruang atau teknis penelitian agar memperoleh data maupun kesimpulan penelitian. Menurut jenisnya, penelitian ini adalah penelitian deskriptif kualitatif dan pada dasarnya bercorak media sosial, yakni semua sumber berdasar pada bahanbahan media sosial yang berkaitan dengan permasalahan yang dibahas.

Penelitian ini dirancang dan didesain secara interpreatif, yaitu menggambarkan dan mendeskripsikan data sesuai dengna interprestasi dan pandangan peneliti tentang niali-niali bahasa Alay dalam media sosial.

Langkah-langkah yang dilakukan yaitu membuat kerangka acuan untuk melaksanakan penelitian. Setelah 
ditentukan rumusan masalah penelitian, peneliti kemudian mengadakan studi online, selanjutnya menyelidiki dan memberikan batasan istilah penelitian, serta menentukan metode yang digunakan dalam peneliti ini.

\section{b. Fokus Penelitian}

Fokus penelitian adalah pemusatan konsentrasi pada tujuan dari penelitin yang dilakukan. Fokus penelitian harus dinyatakan secara eksplisit untuk memudahkan peneliti sebelum melakukan observasi. Fokus penelitian merupakan garis besar dari pengamatan penelitian sehingga observasi dan analisa hasil penelitian lebih terarah. Adapun fokus penelitian dalam penelitian ini adalah nilai moral bahasa Alay.

\section{HASIL PENELITIAN DAN PEMBAHASAN}

A. Penyajian Hasil Analisis Data

Pada bab ini, penulis menyajikan hasil analisis data yang menitik beratkan pada kajian nilai moral pada bahasa Alay di media sosial. Untuk menghindari adanya ketumpangtindihan, maka penulis membagi membagi nilai moral menjadi beberapa kategorin yaitu nilai pendidikan agama, nilai pendidikan budaya dan nilai pendidikan psikologis.

Sebelum penulis menyajikan hasil analisis data yang terdapat dalam nilai moral bahasa Alay, terlebih dahulu penulis memaparkan secara jelas pengertian beberapa aspek yang menjadi fokus sentral dalam penelitiaan ini.

\section{Nilai Pendidikan Agama}

Agama adalah undang-undang atau peraturan yang mengikat hubungan manusia dengan Allah Subhanahu wa ta'ala, kemudian hubungan manusia dengan sesama manusia serta hubungan manusia dengan alam.

Menurut KBBI agama adalah, sistem yang mengatur tata keimanan (kepercayaan) dan peribadatan kepada Tuhan yang Maha Kuasa serta tata kaidah yang berhubungan dengan pergaulan manusia dengan manusia serta lingkungannya.

\section{a. Etika Berbicara}

Di era globalisasi bahasa Indonesia yang baik dan benar semakin jarang dipakai. Seiring Perkembangan zaman modifikasi bahasa berubah menjadi bahasa gaul yang membawa pengaruh besar dalam kehidupan sehari-hari maupun dalam pembentukan kepribadian seseorang. Seperti masyarakat kota pada umumnya, perkembangan trend yang semakin kompleks ini menyebabkan masyarakat yang kurang memahami trend menjadi salah kiblat dan menyimpang dari trend yang sebenarnya. Salah satunya trend di negara Indonesia yang bermula dari kesalahpahaman saat ini adalah trend berbahasa. Perkembangan mode teknologi terutama berkembangnya status jejaring sosial saat ini yang telah banyak diikuti dan sudah menjamur oleh para kaum remaja yang tergolong masih labil. Dari mulai perubahan cara berbicara, cara menulis, bergaul, bahkan cara berpakaian yang berbeda-beda yang seharusnya mudah menjadi lebih rumit dan bahkan jauh dari tata cara berpakaian yang diajarkan dalam islam. Boleh saja menggunakan bahasa alay dalam pergaulan sesama remaja, tetapi terkadang mereka juga menggunakannya dalam berkomunikasi dengan orang lain, baik itu kepada anak kecil maupun orang dewasa, umpamanya orangtua dan guru. Mungkin, 
para remaja itu lupa bahwa mereka perlu belajar untuk menempatkan diri, termasuk dalam berkomunikasi dan berbahasa, dengan siapa mereka berhadapan. Jadi kesannya para remaja zaman sekarang seperti tidak mempunyai etika berbeda dengan anak-anak dahulu.

Bermula dari sebuah lagu, kata Alay alias Anak Lebay menjadi lebih sering digunakan untuk orang-orang yang memiliki perilaku seperti diatas. Namun, tahukah anda apa arti Alay yang sebenarnya? Selain diartikan sebagai anak lebay, alay pun memiliki singkatan anak layangan. Berbicara tentang hal tersebut,para pakar/ahli psikologi pun ikut berbicara. Alay sebetulnya merupakan gejala alami yang kini sedang terjadi pada anak muda yang ingin diakui statusnya di antara teman-temannya, yang membuat dia merasa lebih cantik, lebih keren, gaul atau lebih hebat diantara teman-temannya lainnya.

Faktor utama penyebab munculnya hal tersebut salah satunya dari media TV, Internet, HP, majalah, atau sosok yang mereka yang kagumi.

Bahasa remaja yang digunakan oleh anak remaja pada zaman sekarang ini, sebenarnya muncul dari kreativitas mereka mengolah kata baku di dalam bahasa Indonesia menjadi kata yang tidak baku. Bahasa gaul dapat timbul dari iklan di televisi, lirik lagu maupun ragam sms.
Bahasa lagu dan lirik lagu biasanya sangat mempunyai peranan penting dalam bagi remaja. Misalnya kata capek deh, sering digunakan remaja dalam kesehariannya bahkan anak-anak kecilpun ikut menirukan kata-kata tersebut. Dalam lirik lagu, misalnya pada kata "mara-mara mara-mara itu nggak perlu udahan marahnya cepetan dong cepetan". Pada novel-novel remaja juga ditemukan bahasa gaul tersebut. Misalnya, novel berjudul "Cintapuccino" dari judulnya saja sudah menggunakan bahasa gaul, apalagi isinya. Terus sms, karena ingin cepat dibalas-menghemat pulsa juga menyingkat waktu, dia menulis "maksi yuk", "lez gpl". Nah kata-kata tersebut memang sebenarnya kata-kata dalam sms, tapi "maksi"(yang berarti terima kasih), dan "gpl" (gak pake lama: Tidak Terlalu Lama) sering sekali dilontarkan oleh anak-anak muda dalam berkomunikasi sehari-sehari. Anak-anak ABG pada era ini menggunakan bahasa gaul dalam kehidupannya sehari-hari, karena mereka merasa cocok dan nyaman dalam menggunakannya. Mereka lebih menemukan jati dirinya sendiri sebagai anak remaja. Dan apabila diantara mereka tidak menggunakannya, mereka dianggap tidak gaul. Dianggap tidak mengikuti perkembangan zaman. Tragisnya dianggap kuper. Dalam konteks demikian, mereka berlomba-lomba belajar bahasa gaul

Contoh Penggalan Bahasa Gaul 
Contoh Penggalan Bahasa Gaul

\begin{tabular}{|c|c|c|}
\hline Alay & Indonesian & English \\
\hline 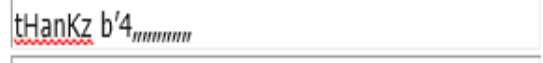 & Terima kasih sebelumnya & Thanks before \\
\hline @q 8kN14h @14Y 8y454 & Aku Bukanlah Alay Biasa & I'm not an ordinary Alay \\
\hline K4m53Up4y & $\begin{array}{l}\text { Kamseupay (Kampungan Sekali Uh } \\
\text { Paxah) }\end{array}$ & Very cheesy/tacky \\
\hline $53 s 5 U 4+u$ D3ch & Sesuatu deh.... & Really something \\
\hline k4m03 1m03t Bu4nGetzzzz d3ch & Kamu imut banget deh & You're so cute \\
\hline T1n4 IUpH u 43VEr & Tina mencintaimu selamanya & Tina loves you forever \\
\hline M4Im1n9 sM@ 4Qoeh e@... & Malam Mingquan Sama Aku ya ... & Spend Saturday night with me, please \\
\hline AkKoehhHh cUIntha KhaMmMukH PholePHEl & Aku Cinta kamu Selamanya & I Love You Forever \\
\hline doN1 cint4 t1n4 5ampai m4t1 ... & Doni cinta Tina sampai mati & Doni loves Tina until dead \\
\hline $\begin{array}{l}\text { INdR4 IUPhH 5un4rTol C3|La4LllU, } \\
\text { 3Mu4Chhh...: : }\end{array}$ & Indra cinta Sunartol selalu, muahhh....** & $\begin{array}{l}\text { Indra always loves Sunartol, (kissing } \\
\text { emo) }\end{array}$ \\
\hline S!thI3 clndTha 84mB@nX 43veR & Siti cinta Bambang Selamanya & Siti loves Bambang forever \\
\hline As3P Pr!L3ncer $50 \mathrm{j} U \mathrm{UTa}$ & Asep freelancer 50 juta & Asep the 50 million freelancer \\
\hline Ciyus? Mi Apa & Serius? Demi apa? & Sure? By what? (Really? So What?) \\
\hline
\end{tabular}

Allah Subhanahu Wa Ta'ala berfirman yang artinya:

"Hai orang-orang yang beriman, bertakwalah kamu sekalian kepada Allah dan katakanlah perkataan yang benar, niscaya Allah memperbaiki amalan-amalanmu dan mengampuni dosa-dosamu. Barangsiapa mentaati Allah dan Rasul-Nya, maka sesungguhnya ia telah mendapat kemenengan yang besar" [Al-Ahzab : 70-71]

Dari terjemahan ayat diatas terlihat jelas bahwa Allah memerintahkan kita untuk berkata (berbahasa) dengan benar, sehingga dapat disimpulkan bahwa bahasa Alay merupakan bahasa yang tidak baik dan kurang benar karena secara tidak sadar bahasa Alay dalam dunia maya (media sosial) akan dapat mempengaruhi terhadap dunia nyata terutama pada perkembangan bahasa Indonesia yang baik dan benar dikalangan remaja.
Menurut pakar komunikasi $70 \%$ dalam 24 jam, waktu manusia diisi dengan komunikasi. Begitu banyaknya waktu yang kita habiskan dalam komunikasi. Salah komunikasi atau misscommunication akan mengakibatkan salah presepsi. Rasulullah Shallalahu 'alaihi wasallam adalah komunikator yang hebat, setiap pesan yang beliau sampaikan pasti berkesan dihati para sahabat, bahkan dihati kaum kafir yang memusuhinya.

Contoh Kasus upload status yang berujung pada hukum, Baru-baru ini seorang remaja yang mengupload sebuah foto di salah satu media sosial, ternyata perbuatan tersebut yang awalnya hanya iseng berujung pada hukum. Mungkin tujuan remaja tersebut hanya ingin menghibur akan tetapi siapa sangka hiburan tersebut berujung dramatis. Oleh karena itu, sebelum kita membuat status terlebih lagi kepada remaja yang notabenenya 
pengguna media sosal, alangkah baiknya dipikirkan terlebih dahulu jangan sampai kasus seperti diatas terulang kembali.

Didalam keseharian kita, ada beberapa halhal yang harus diperhatikan yaitu:

- Bagaimana saya harus berbicara?

- Bagaimana memilih kata-kata yang tepat dalam berbicara?

- Bagimana menguasai materi agar pembicaraan tidak ditertawakan orang?

- Kenapa setiap ide yang saya coba utarakan ternyata hilang?

- Bagimana memulai pembicaraan?

Sederetan pertanyaan itulah yang kerap kali kita jumpai, mungkin juga pernah atau bahkan sedang mengalami hal seperti itu. Pertanyaan-pertanyaan itu tentu tidak salah untuk diutarakan, dan pertanyaan tersebut perlu dicari solusinya. Dengan berbagai langkah, tentu kita harus dapat berbicara dengan fasih dan lancar sebagaimanan kedua orang tua kita mengajari kita supaya bisa berbahasa dengan benar, fasih jelas, dan dapat dipahami.

Akan tetapi pada fase berikutnya kita harus juga melatih diri dengan mempertanyakan berbagai hal yang terkait dengan apa yang telah kita katakan. Beberapa pertanyaan yang layak untuk dikedepankan antara lain:

1. Apakah pertanyaan saya menyakiti orang lain?

2. Apakah ucapan saya sudah benar?

3. Bagaimana dampak dari apa yang saya ucapkan?

4. Kenapa saya membicarakan tema yang membuat orang lain tertarik?

5. Apakah ucapan saya akan mendatangkan kemaslahatan (manfaat) ataukah justru mendatangkan mudharat (kerugiaan) Adapun Bentuk-bentuk Penyelewengan Lidah, yaitu sebagai berikut:

a. Ghibah
Ghibah adalah perbuatan membicarakan sesuatu yang sebenarnya tentang orang lain dan membicarakannya dibelakang alias tidak ada orang yang bersangkutan. Ghibah ini hampir menyerupai perbuatan gosip, sebagimana yang sering kita saksikan di tengah kehidupan sehari-hari. Bahkan, acara-acara yang berisi gosip, fitnah dan juga prasangka yang dipertontonkan dimedia massa tak terkecuali di media sosial.

Contoh kalimat yang merupakan bagian dari ghibah yaitu,

"Si Pardan itu orangnya memang kaya raya, selain kaya dia juga suka bersedekah kepada teangganya, anak-anak yatim dan rajin beribadah lagi.

Sekalipun kalimat itu memuji si Pardan tetapi jika si Pardan tidak suka dan merasa terlalu berlebihan maka pembicaraan tersebut menjadi bagian dari ghibah. Ghibah merupakan perkara yang jauh dari kebenaran. Bahkan terkadang terdapat unsur propoganda yang tidak sesuai dengan kebenarannya.

Kita harus berhati-hati dengan ghibah, karena tidak jarang perbuatan tersebut disebarluaskan dimedia salahsatunya dimedia sosial. Akibatnya seringkali kita jumpai aktivitas ini berujung pada hukum. Misalnya, kasus penghinaan terhadap Guru, Bupati, Gubernur atau bahkan kepada Presiden. Berawal dari keisengan mengupload status yang tujuannya hanya untuk hiburan akan tetapi justru malah mengandung penghinaan. Maka tidak menutup kemungkinan bahasa Alay pun bisa saja berujung seperti kasus diatas.

b. Namimah dan Fitnah

Namimah merupakan perbuatan yang masih satu rangkaian dengan gosip.Dengan kata lain, namimah sama halnya dengan fitnah. Namimah atau membuka rahasia orang lain merupakan perbuatan dosa, sebab 
bagiamanpun jika dalam diri setiap orang mempunyai privasi dan kecenderungan menutupi aibnya sendiri, jika ada pihak lain yang membuka aibnya tentu sangat menyakitkan. Masih segar dalam ingatan ketika salah seorang anggota DPR-RI yang mengeluarkan statemen bahwa presiden Susilo Bambang Yudhoyono sudah menikah dengan wanita lain dan sudah menceraikannya sebelum menikah dengan Ibu Any Yudhoyono. Kabar ini membuat sang Peresiden marah hingga akhirnya melaporkan hal itu kepada aparat kepolisian.

Dalam perkembangan dunia modern ini, perbuatan namimah relatif lebih mudah dilakukan daripada di zaman dahulu yang belum tersedia berbagai kemudahan dalam bidang teknologi. Untuk menyebarkan berita bohong tidak perlu dengan keliling dan mengungkapkan fitnah secara langsung kepada pihak lain, melainkan dapat digunakan dengan fasilitas teknologi seperti sarana internet. Fasilitas ini rata-rata notabenenya adalah remaja dan tentunya para remaja perlu berhati-hati mengakses berita di internet.

b. Munafik

Munafik sama halnya dengan bermuka dua atau sama halnya orang yang menghendaki hidup berada dalan dua lingkungan. Sifat orang yang bermuka dua adalah, apabila berbicara ia berdusta, apabila berjanji ia mengkhianati dan apabila berbicara selalu berbohong.pun ciri-ciri orang munaik diantaranya sebagai berikut,

- Mudah berbohong dan mengelabui orang

- Lidahnya sangat fasih dalam menggunakan kata-kata

- Suka memuji, sekalipun pujian ini tidak semestinya diucapkan. Pujian tersebut hanya semata-mata untuk kepentingan sendiri.
Sifat ini tak jarang kita jumpai baik di dunia nyata maupun di dunia maya. Maka hal seperti ini perlu diwaspadai terlebih lagi dimedia sosial.

\section{c. Dusta atau Bohong}

Bahaya lidah yang lain adalah dusta atau bohong. Seseorang yang berdusta tidak lain adalah untuk menutupi diri dari kebenaran. Perbuatan ini perlu diwaspadai terlebih lagi dimedia sosial. Apatah lagi kasus penipuan di media sosial lagi marak. Berawal dari pertemanan facebook, bagi remaja cewek memajang foto-foto yang menawan disertai foto-foto yang berbaur alay. Meskipun tidak dipungkiri bahwa apakah foto tersebut foto asli atau hanya rekayasa. Para remaja cowok pun terkadang tidak mempermasalahkannuya yang penting foto tersebut dianggap cantik dan gaul. Begitupula sebaliknya. Selang kemudian keduanya bertukar komentar, akhirnya kasus seperti ini tidak jarang berujung pada kasus penculikan.

Tidak ada yang menjaga hak-hak perempuan di internet" Ungkap Nani Buntarin, aktivis perempuan yang sejak tahun 1998 menginisiasi pengguna mailing list untuk gerakan perempuan. Hali ini terungkap dalam diskusi Perempuan di Kedai Tjikini, Rabu, 24/10/2012 lalu. Dalam acara yang diselenggarakan oleh Komnas Perempuan bekerjasama dengan Jaringan Perempuan Eksplorasi Hak Internet dan Seksualitas tersebut, terungkap berbagai pengalaman kekerasan terhadap perempuan di internet. Sebuah media memberitakan belum lama ini pihak kepolisian berhasil mengungkap kejahatan yang menawarkan peempuan secara online. Sangat memprihatinkan karena kejahatan tersebut baru terungkap setelah dua tahun beroperasi.

d. Takabur atau Sombong 
Bahaya lidah yang lain adalah takabur atau sombong. Kesombongan seringkali dilakukan seseorang karena dipengaruhi oleh penyakit hati dalam bentuk tidak percaya diri atas apa yang dimiliki, sehingga seseorang cenderung membuat pernyataan yang merendahkan orang lain alias sombong. Jika kita selidiki, kecenderungan berlaku dan bersikap sombong ini terkait dengan rasa minder yang berlebihan dan akhirnya seseorang tersebut ingin menunjukkan kepada orang lain dengan menceritakan berbagai kelebihannya guna menutupi berbagai kelemahan yang ia miliki. Tetapi, juga terkadang orang sombong ini dilakukan oleh orang yang memiliki kelebihan harta, pangkat dan jabatan. Sehingga perilaku ini tidak menutup kemungkinan ia juga pamerkan dimedia sosial yang telah menjadi gaya hidup terutama para remaja.

\section{e. Berkhianat}

Pernahkah orang lain membuat perjanjian dengan Anda? Bagaimana bahagianya Anda, jika orang tersebut menepatinya? Bagaimana pula jika seorang tersebut menghianatinya? Oleh sebab itu, hendaknya kita harus jeli ketika menghadapi segala permasalahan yang berkaitan dengan orang lain. Pada zaman sekarang ini, dengan modal kepercayaan saja tidak cukup karena akan dengan mudah dikhianati atau bahkan ditipu.

Salah satu problem bangsa Indonesia sekarang ini adalah keberadaan para pemimpin yang terkadang tidak amanah. Mereka mengingkari janji yang telah mengingkari janji yang telah ia ucapkan. Tentu hal ini termasuk dalam kategori pengkhianatan, bahkan janji-janji mereka juga diumbar dimedia sosial. Sehingga perilaku ini bisa saja dicontohi para remaja yang notabenenya adalah pengguna media sosial.

f. Sumpah Palsu
Kadangkala, seseorang tidak sadar bahwa ia telah mengucapkan sumpah. Sumpah seringkali dinyatakan untuk meyakinkan orang lain. Begitu pula para remaja yang sebagian dari mereka tidak hafal dengan sumpah pemuda bahkan mereka malah mengedit teksnya dalam bahasa alay. Seperti yang tercantum dibawah ini

"K4mi putr4-putr1 Indon3sia mEn9aku bertump4h darah yan9 satu, tanah 4ir

K4mi putr4-putr1 Indon3sia men9aku BerbaNgsa satu,BanGsA Indonesia

K4mi putr4-putr1 Indon3sia MenJunJung bahaSapErsaTuan, BaH4sa Indon3sia"

Teks diatas tentunya mencemarkan sumpah pemuda terlebih lagu ejaan bahasa Indonesia. Adapun Tata Cara Memaniskan Lidah, yaitu sebagai berikut:

a. Berdzikir Kepada Allah Subhanahu Wa Ta'ala

b. Berbicara yang Berfaedah

c. Memberi Nasihat-nasihat

d. Jadikan Lidah Sebagai Corong dan Cermin

e. Memperbanyak Membaca Al-Qur'an

f. Memnyebarkan Salam

Salah satu gejala negatif bahasa gaul mempunyai dampak pada perilaku yang tidak baik bila digunakan pada orang yang lebih tua. Untuk itu bahasa gaul kurang baik karena keluar dari tatanan norma sopan santun.

\section{b. Etika Menggunakan Waktu}

Umumnya orang-orang tidak menyadari bahwa dirinya telah menghabiskan waktu berjam-jam hanya untuk melihat status atau mengomentarinya. Orang yang status/tweet/foto-nya dikomentari oleh banyak orang akan merasa dirinya "eksis". Sehingga orang itu akan memposting lebih banyak lagi status atau foto meskipun isinya cukup Pada account facebook, twitter, instagram bagi yang cewek di album fotonya memajang cowok-cowok 
ganteng meskipun tidak kenal supaya dianggap cantik dan gaul. Untuk yang cowok, memajang foto cewek semua walau tidak kenal agar disangka cowok ganteng. Banyak yang tidak menyadari bahwa internet juga menjadi ranah kejahatan terhadap perempuan. "Tidak ada yang menjaga hakhak perempuan di internet" Ungkap Nani Buntarin, aktivis perempuan yang sejak tahun 1998 menginisiasi pengguna mailing list untuk gerakan perempuan. Hali ini terungkap dalam diskusi Perempuan di Kedai Tjikini, Rabu, 24/10/2012 lalu. Dalam acara yang diselenggarakan oleh Komnas Perempuan bekerjasama dengan Jaringan Perempuan Eksplorasi Hak Internet dan Seksualitas tersebut, terungkap berbagai pengalaman kekerasan terhadap perempuan di internet.

Sebuah media memberitakan belum lama ini pihak kepolisian berhasil mengungkap kejahatan yang menawarkan peempuan secara online. Sangat memprihatinkan karena kejahatan tersebut baru terungkap setelah dua tahun beroperasi.

Suka mengirim 'status' tidak jelas dengan memakai bahasa alay misalnya "ngantuk tidur yuk" Kalimat tersebut memang sepele. Namun, bagi mereka yang belum tahu adabadab berbicara dengan lawan jenis maka akan berbeda hasilnya. Benar saja, berbagai komentar segera muncul menanggapi status tersebut. Ada yang menanggapi serius tetapi kebanyakan hanya menggoda bahkan beberapa menggoda lebih jauh lagi, menjurus kehubungan pasutri.

Menganggap dirinya eksis di Friendster atau Facebook atau Multiply (kalau

comments banyak berarti anak gaul, menjadi lomba banyak comment)

Curhat (curahan hati) memang menyenangkan. Namun, sebaiknya lihatlah tempat jika ingin curhat dan gunakan cara yang konvensional dibanding melakukannya di media pertemanan tersebut. Jika semua permasalahan yang Anda ditampilkan maka Anda bisa dianggap tidak profesional. Sebaiknya tuliskan hal-hal yang lebih positif yang membuat orang lain bersemangat.

Kalau ada orang yang hanya melihat profil user di media sosial, lalu mengirim testimonial: "hey cuman view nih?" atau "heey jgn cuman view doang, add dong! Jawablah pesan dari teman Anda jika mereka menanyakan sesuatu. Namun, abaikan saja jika ada yang mengirimkan pesan negatif. Link aktif atau tautan yang tersebar diberbagai situs, grup atau komentar semakin banyak. Namun, sebaiknya Anda jangan sembarang mengikutinya karena sebagian link biasanya hanya jebakan.

Nama profil media sosial mengagungagungkan diri sendiri, seperti: Bocah nakal, gadis liar dan lain-lain. Padahal sudah dikabarkan dalam sebuah ayat bahwa janganlah saling memanggil dengan gelargelar yang buruk. Seburuk-buruk panggilan adalah adalah panggilan yang (fasik) setelah beriman. Dari ciri-ciri diatas, dapat diketahui bahwa bahasa Alay sudah berkembang pesat dimedia sosial terutama facebook dan twitter.

Bahasa gaul ditawarkan dan dikonsumsi oleh masyarakat modern yang mempunyai ciri gaya hidup meningkat, akan tetapi bagi kelompok sosial yang mudah dibentuk oleh pasar akan terjadi konstraksi antara nilai tradisional dan masyarakat modern. Sehingga menggiring kaum muda untuk tidak hemat pada pola hidup yang sederhana. Apabila sikap ini dipupuk akan menimbulkan masalah sosial besar bagi yang mengkonsumsi bahasa gaul maka mempengaruhi pola hidup yang serba gemerlap. Bila remaja yang tingkat sosialnya rendah bisa timbul rasa frustasi, secara psikologis akibat yang buruk karena bahasa gaul sering digunakan para remaja modern yang tingkat sosialnya tinggi. Dengan adanya bahasa gaul akan mempengaruhi perilaku 
remaja, untuk itu remaja di didik untuk mengkonsumsi barang-brang tertentu sebagai indikator bahwa mereka adalah bagian dari remaja gaul, remaja berkeinginan memiliki barang-barang yang abaru sedangkan yang lama sudah dianggap ketinggalan zaman dan remaja merasa rendah apabila bertemu atau berkomunikasi dengan teman-temannya karena bahasa atau barang-barang yang tidak gaul.

Internet sebagaimana yang telah kita ketahui bersama,memiliki manfaat yang sangat banyak diantaranya sebagai media informasi dan komunikasi bagi seluruh umat manusia di dunia. kita bisa saling berkomunikasi dengan keluarga yang jaraknya menurut logika sangant jauh seperti diluar negri,akan tetapi dengan adanya internet semua itu bukanlah penghalang untuk dapat saling berkomunikasi dengan keluarga tercinta. Maka dari itu kita harus pandai-pandai dalam memanfaatkanya. Misalnya kita tidak melalaikan waktu di depan internet hanya untuk sekedar bermain game online,chatting,melihat hal-hal yang tidak penting tanpa batas waktu.

Diantara perkara penting yang perlu diperhatikan ketika kita menggunakan internet adalah :

1. Gunakan internet untuk hal yang bermanfaat

Waktu adalah nikmat yang sangat besar,akan tetapi banyak orang-orang yang menyia-nyiakan waktu hanya untuk keperluan yang kurang penting atau bahkan sia-sia

\section{Menjaga pandangan mata}

Dalam dunia internet tidak akan bisa lepas dari gambar-gambar yang haram untuk dilihat,seperti gambar wanita yang auratnya terbuka,bahkan ada yang sampai telanjang. Oleh karena itu sudah diharuskan bagi kita untuk menjaga pandangan mata agar kita tidak terjerumus kepada hal-hal yang tidak di inginkan.

Sebagaimana dalam hadist rosulluloh saw yang artinya :

“ tidaklah aku tinggalkan setelahku fitnah yang lebih berbahaya bagi laki-laki dari pada fitnahnya wanita" (Hr.Bukhori dan Muslim)

3. Senantiasa merasa dalam pengawasan Allah Subhanahu Wa Ta'ala

Inilah hal yang sangat penting bagi kita saat berada di dunia maya,yaitu menghindarkan hati agar senantiasa merasa diawasi oleh Allah Subhanahu Wa Ta'ala, sebagaimana dalam firman Allah dalam surat al-baqarah ayat 235 yang artinya :

"Dan ketahuilah bahwasanya allah mengetahui apa yang ada di dalam hatimu, maka takutlah kepada-Nya"

\section{a. Bahasa Alay/gaul}

Di Indonesia, perkembangan bahasa terjadi dengan cukup cepat. Mengingat Indonesia memiliki lebih dari 700 bahasa daerah serta bahasa persatuan yang kesemuanya mengalami berbagai dinamika dan strateginya masing-masing dalam menghadapi terjangan bahasa asing maupun bentuk perkembangan bahasa lainnya. Masyarakat bahasa, terutama yang berada di masyarakat perkotaan akan semakin mudah menerima berbagai unsur yang masuk dalam mempengaruhi perkembangan bahasa. Pada masyarakat bahasa, terdapat sikap bahasa yang dimiliki oleh masyarakat bahasa dalam menyikapi kebahasaan mereka. Menurut Anderson, sikap bahasa adalah tata keyakinan atau kognisi yang relatif berjangka panjang, sebagian mengenal 
bahasa, mengenai objek bahasa, yang memberikan kecendrungan kepada seseorang untuk bereaksi dengan cara tertentu yang disenanginya. Sikap bahasa itu bisa positif jika dinilai disukai atau bisa negatif jika tidak disukai. Sikap bahasa inilah yang digunakan masyarakat dalam menyikapi berbagai fenomena kebahasaan yang dewasa ini begitu banyak terjadi di masyarakat Indonesia.

Fenomena kebahasaan yang kini begitu booming terjadi adalah maraknya penggunaan kata-kata gaul oleh remaja Indonesia, khususnya remaja perkotaan di kehidupan sehari-harinya. Adapun penggunaan bahasa gaul yang saat ini marak digunakan oleh remaja, baik yang masih duduk di bangku sekolah atau bahkan yang tidak mengenyam pendidikan adalah bahasa-bahasa gaul yang sejatinya diperkenalkan oleh media massa elektronik seperti iklan di televisi, sinetron khusus remaja, atau bahkan bahasa yang digunakan oleh selebriti di infotainment. Kata-kata yang merujuk pada bahasa gaul yang booming kini seperti ciyus 'serius', miapah 'demi apa', enelan 'beneran' dan masih banyak lagi. Sepintas, kata-kata seperti itu terkesan lumrah terdengar sehari-hari. Nilai Psikologis

\section{a. Gaya Hidup}

Di era modern, manusia dipermudah dalam melakukan berbgai hal. Slah satu kemudahan yang dicitakan adalah berinteraksi melalui internet. Semakin berkembangnya internet maka otomatis pola komunikasi pun semakin berkemababng tak terkecuali dengan bahasa Alay atau bahasa gaul. Munculnya bahasa Alay menunjukkan adanya perkembangan zaman yang dinamis, karena suatu bahasa harus menyesuaikan dengan masyarakat penggunanya agar tetap eksis. Bahasa gaul ditawarkan dan dikonsumsi oleh masyarakat modern yang mempunyai ciri gaya hidup meningkat, akan tetapi bagi kelompok sosial yang mudah dibentuk oleh pasar akan terjadi konstraksi antara nilai tradisional dan masyarakat modern. Sehingga menggiring kaum muda untuk tidak hemat pada pola hidup yang sederhana. Apabila sikap ini dipupuk akan menimbulkan masalah sosial besar bagi yang mengkonsumsi bahasa gaul maka mempengarujlhi pola hidup yang serba gemerlap. Bila remaja yang tingkat sosialnya rendah bisa timbul rasa frustasi, secara psikologis akibat yang buruk karena bahasa gaul sering digunakan para remaja modern yang tingkat sosialnya tinggi.

\section{b. Pola Pikir}

Banyak orang lebih memilih komunikasi melalui jejaring sosial ketimbang berbicara secara langsung. Itu karena otak mereka tidak pernah dilatih untuk berpikir cepat saat mengobrol. Kebiasaan chatting membuat orang dapat menunda membalas pesan dari seseorang. Ini tentu saja berbeda dengan komunikasi langsung yang menguras konsentrasi dan pikiran. Bahkan saat ngobrol di restoran, mereka lebih memilih mengutak-atik ponselnya ketimbang ngobrol dengan orang yang ada didepannya. Internet telah menghancurkan hidup kita dan merusak moral kita. Kita telah menjadi orang yang menghabiskan waktu berjam-jam di internet hanya untuk membuang-buang waktu. Bahkan seringkali kita mengakses situs pornografi yang sangat merusak moral. Ini sangat memalukan dan merusak moral manusia. Dengan adanya internet, kita menjadi lebih mudah untuk saling bertukar konten pornografi. Meskipun Kementerian Komunikasi dan Informatika sudah bekerja keras untuk mencekal ratusan situs 
pornografi, namun tetap saja pecandu pornografi tidak kehabisan akal untuk mengakses kembali situs tersebut. Bahkan saat ini telah menjadi sebuah bisnis yang bernilai milyaran Rupiah.

Jika kita pernah melihat dan mendengar seseorang bahasa alay secara lisan, maka cobalah perhatikan saat dia berbicara dari gerak-gerik mulut dan sikapnya maka akan terlihat bahwa bahasa alay itu sangat berdampak negatif. Kebanyakan dari mereka yang setia dengan bahasa alay akan cenderung memiliki sesuatu yang berlebihan. Kepercayaan dirinya berlebihan, saat dia berbicara gerakan badan yang dipergunakanpun berlebihan. Hal tersebut dapat tercermin dengan beberapa tingkah yang dilakukannya. Misalnya saja, ketika dia bercerita dengan seseorang tubuhnya tidak pernah diam, intonasis saat dia berbicara tidak jelas karena orang yang menggunakan bahasa Alay itu kata-katanya bernada ditekankan atau direndahkan.

\section{DAFTAR PUSTAKA}

Abu Hamzah, Al-Ustad 2013. Majalah Qonitah: Petaka Dunia Maya. Sleman: Muslim Takwa Media.

Al-Bani, M. Nashiruddin. 2005. Ringkasan Shahih Muslim. Jakarta: Kalam Mulia

Alwi, Hasan, Soenjono Dardjowidjojo, dkk. Tata Bahasa Baku Bahasa Indonesia. Edisi Ketiga. Jakarta: Balai Pustaka

Anjoyo, Muhammad. 2014 "Pengaruh bahasa gaul dalam perkembangan bahasa Indonesia" http://wartawarga.gunadarma.ac. id
Anwarul, Andri. 2012 "Makalah Pengaruh Bahasa Gaul Dalam Perkembangan Bahasa Indonesia

"electroh311.blogspot.com

Ashadi, Siregar. 2004. Popularisasi Gaya Hidup: Sisi Remaja dalam Komunikasi Massa. Lifestyle Ecstasy. Idi Subandi Ibrahim Yogyakarta: Jalasutra.

Azis, $\quad$ Firman."Makalah-PenggunaanBahasa-Gaul-MempengaruhiEksistensi- BahasaIndonesia" "http://www.slideshar e.net/riskia-chandra

Barker, Chris. 2009. Cultural Studies Teori dan Praktik. Penerjemah Nurhadi. Yogyakarta: Kreasi Wacana.

Barnard, Malcolm. 2011. Fashion Sebagai Komunikasi. Yogyakarta: Jalasutra.

Budiman, Hiikmat. 2008. Lubang Hitam Kebudayaan. Yogyakarta: Kanisius.

Chaer, Abdul dan Leonie Agustina. 2010. Sosiolinguistik Perkenalan Awal Jakarta: Rineka Cipta

Chaney, David. 2011. Lifestyle; Sebuah Pengantar Komprehensif. Penerjemah Nuraeni. Yogyakarta: Jalasutra.

Farizah Abu, 2013. Curhat DI Facebook? Sukohardjo: Sakinah

Ibrahim, Idi Subandi. 2010. Memahami Mitos-mitos Budaya Populer dalam "Masyarakat Komunikasi" Mutakhir (sebuah pengantar).

Izah, Abu 2013. Update Status. Sukohardjo:Sakinah 
Kridalaksana, Harimurti. 1985. Fungsi Bahasa dan Sikap Bahasa. Flores: Nusa Indah.

Mubin Nurul, 2012. Misteri Lidah Manusia: Yogyakarta: Sabil

Mustakim. 1994. Membina Kemampuan Berbahasa: Panduan ke Arah Kemahiran Berbahasa. Jakarta:

Pangabean, Maruli. 2006. Bahasa Pengaruh dan Peranannya. Jakarta: Gramedia. PT Gramedia Pustaka Utama.

Nababan , P.W.J. 1993. Sosiolinguistik: Suatu Pengantar. Jakarta : Gramedia Pustaka Utama.

Ristika,Irni. 2011. " Pengaruh Bahasa Gaul dalam Perkembangan Bahasa Indonesia", http://theniesland.blogspot.com

Ritzer, George. 2007. Sosiologi Ilmu Pengetahuan Berparadigma Ganda. Jakarta:

PT Raja Grafindo Persada.

Salamah, Nur. "Penggunaan bahasa dalam Pers dalam media "http://salmahsemangat.blogspot.com/2010/04/

Santoso, Kusno Budi. 1990. Problematika Bahasa Indonesia. Bandung: Angkasa.

Sarwono, Sarlito W. 2003. Psikologi Remaja. Jakarta: PT. Grafindo Persada.

Strinati, Dominic. 2009. Popular Culture: Pengantar Menuju Teori Budaya
Populer.
Penerjemah
Abdul
Muchid.Yogyakarta: Ar-Ruzz
Media.

Sulaiman al-Umar bin Nashir. 2001. Tasir Surat al-Hujurat. Jakarta: AlKautsar

Sumarsono. 2007. Sosiolinguistik. Yogyakarta: SABDA.

SVD, Bernard Raho. 2007. Teori Sosiologi Modern. Jakarta: Prestasi Pustaka.

Wilis, Sofyan S. 1994. Problema Remaja dan Pemecahannya. Bandung: Angkasa

Wulandari, 2012."Penggunaan-bahasa-alaydalam-jejaring-sosial "http://bahasa.kompasiana.com 